\title{
Jægeren, de venlige jaguarer og honningfesten
}

\section{Om Claude Lévi-Strauss' miskendelse af animismen og den påståede afbrydelse af forbindelsen imellem himmel og jord}

\author{
HANS J. LUNDAGER JENSEN
}

ENGELSK SUMMARY: This brief article is an addition to my introduction to Philippe Descola's theory on ontologies available in this volume of RvT. Inspired by a South American myth about helpful jaguars, I discuss Lévi-Strauss' miscomprehension of the animist ontology, which paradoxically pervades the Amerindian myths analyzed in detail in his Mythologies and other works. I also propose a reason for this miscomprehension. At the end of the fourth and final volume on Amerindian mythology, The Naked Man, Lévi-Strauss suggested that the multitude of myths must be regarded as variants of one single conception: an irreversible loss of communication between heaven and earth. However, this conclusion appears as an indirect apology for a naturalistic modernity, based on a confusion between animist and analogist ontologies.

DANSK RESUME: Denne mindre artikel ligger $i$ forlængelse af min redegørelse for Descolas ontologi-teori i dette nummer af RvT. Ud fra en overvejelse over en sydamerikansk myte om hjxlpsomme jaguarer drøftes Lévi-Strauss' misforståelse af den animistiske ontologi, som, paradoksalt nok, er massivt til stede $i$ de amerindiske myter der analyseres så indgående $i$ hans Mythologiques og andre steder. Jeg foreslår en årsag til denne miskendelse. I slutningen på det fjerde og sidste bind af Mythologiques, foreslog Lévi-Strauss at se alle de mange myter som variationer over ét og samme tema: et uigenkaldeligt tab af kommunikation imellem himmel og jord. Men denne konklusion forekommer mest at fungere som en indirekte apologi for en naturalistisk modernitet, baseret på en sammenblanding af animistisk og analogistisk ontologi. 
I forlængelse af redegørelsen for Descolas skemaer over dominerende ontologier og relationstyper i min artikel "Virkeligheder og religionshistorie: En introduktion til ontologier ifølge Philippe Descola" bragt i dette nummer af RvT følger her en overvejelse over Claude Lévi-Strauss' myteanalyser i det store værk Mythologiques 1-4 og i mindre bøger. ${ }^{1}$ Min overvejelse skyldes to forhold. For det første er Descola elev af ikke mindst Lévi-Strauss og som ham amerikanist med speciale og feltarbejdserfaring fra lavlandskulturer i Sydamerika; der er altså en ganske tæt forbindelse imellem deres respektive forskning. For det andet hører alle de mange myter som Lévi-Strauss har undersøgt så grundigt, hjemme i en animistisk ontologi. Faktisk kan hans bøger om myter også og med ganske stort udbytte læses som et stort kompendium af animistiske myter. Så langt er der fuld kontinuitet imellem mesteren og hans elev, ikke kun i deres generelle strukturalistiske tilgang til antropologi, men også med hensyn til empiri, hvad animismen angår.

Der er dog en ting der kan undre. Når man tager i betragtning at Lévi-Strauss har analyseret flere tusind animistiske myter, er det slående at deres animistiske karakter konsekvent henstår sløret. Jeg sigter her ikke til at Lévi-Strauss ikke selv brugte selve begrebet 'animisme'. Det er først Descola der har revitaliseret det, og Lévi-Strauss så formentlig dens ældre, tylorske, betydning som vildledende og uanvendelig. Men selve sagen, altså den animistiske ontologi ifølge Descola, er heller ikke klar hos LéviStrauss. Man kan arbejde sig igennem de tusind myter og flere tusind sider analyser uden at animismen bliver tydeligt forklaret. Den følgende overvejelse, og kritik, formindsker i øvrigt på ingen måde i mine øjne betydningen af den lévi-strausske myteanalyse. Jeg betragter den nu som før som et mesterværk, et højdepunkt i det 20. århundredes antropologi og uomgængeligt for en religionsvidenskabelig (og megen anden) forståelse af narrative og rituelle betydninger. ${ }^{2}$ Men sagen er en overvejelse værd.

\section{Jægeren, de venlige jaguarer og honningfestens oprindelse}

Jeg vil indlede min overvejelse med at parafrasere en myte fra andet bind af Mythologiques, Du Miel aux cendres ('Fra honning til aske') om oprindelsen til Tenetehara-folkets honningfest: ${ }^{3}$

1 De fire bind af Mythologiques er Le Cru et le cuit (1964); Du Miel aux cendres (1966); L'Origine des manières de table (1968); L'Homme nu (1972); de mindre er bøgerne Le Voie des masques (1979); La Potière jalouse (1985); Histoire de Lynx (1991). Dertil kommer talrige artikler.

2 At det også i passager er uigennemskueligt og for mange læsere, inklusive mig selv, vanskeligt forståligt, bør nævnes; der er flere gode grunde, ud over det blotte omfang, til at det ikke er læst af ret mange. Men det samme kan siges om så mange andre mesterværker.

3 Lévi-Strauss 1966, 25-27; myten har indeksnummer M188. Tenetehara (andet navn: Tembé) er en stamme der lever i det nordøstlige Brasilien (i staten Maranhão); Lévi-Strauss' kilde er Wagley \& Galvão 1949, $143 f$. 
En jæger klatrer op i et træ for at jage araer. Da han vil klatre ned, overraskes han af en flok jaguarer, der kommer for at samle honning; først da de er gået igen, tør han klatre ned og vende hjem med sit bytte. Jægernes bror efterligner ham; men han prøver uforsigtigt at skyde en af jaguarerne og bliver dræbt på stedet. Jægeren går ud for at lede efter sin bror, følger blodsporet og kommer til en myretue. Da han er en shaman, kan han skabe sig om til en myre og trænge ind i boet og komme ned til jaguarernes landsby. Her genskaber han sin menneskelige skikkelse og gifter sig med en jaguarkvinde. Hun er datter til den jaguar som havde dræbt hans bror; men drabet var berettiget for det var broderen der uden anledning havde beskudt jaguaren. Helten deltager i forberedelserne til jaguarernes honningfest og lærer alle dens ritualer, sange og danse. ${ }^{4}$ Senere vil han besøge sin menneskefamilie. Han tager sin nye kone med sig, men lader hende vente uden for landsbyen. Da han endelig vil præsentere hende, er hun forsvundet, og jægeren kan ikke genfinde vejen til myretuen. Men han belærer sine medmennesker om hvordan honningfesten skal fejres. Den bliver den vigtigste af de årlige fester, med gæster fra nabolandsbyer, store mængder af føde; festen giver held i jagt det følgende år.

De animistiske træk i denne fortælling er tydelige. Jaguarer og mennesker lever i hver sin landsby. Jaguarerne kan det samme som menneskene: tale, huske, ræsonnere, bo i en landsby, have ægteskabsforbindelser. Når de er hjemme hos sig selv i deres egen, underjordiske landsby, har de aflagt deres jaguarkostume og fremtræder i deres indre, menneskelige, skikkelse. Samtidig kan de mere end almindelige mennesker: Deres jaguarkroppe gør dem stærkere, og de har et rigere kulturelt liv, for de kender en fest som dengang var ukendt for menneskene.

Mange vil genkende grundforløbet i denne myte fra den mere berømte 'fugleredeplyndrermyte', udgangspunktet for Lévi-Strauss' Mythologiques. ${ }^{5}$ Den fortæller om hvordan en dreng der er efterladt på en klippeside eller i et træ, hjælpes ned af en jaguar der tager ham med hjem og introducerer ham til ild og stegt kød, som hidtil var ukendt, adopterer ham (trods sin kones aggressive modvilje) og til sidst lader ham bringe ilden og kulturgoder som bue og pil til menneskene, mens jaguaren selv beslutter sig til at spise sit kød råt. Begge fortællingers helte er altså 'fugleredeplyndrere', der konfronteres med jaguarer der både har en venlig og en destruktiv side, og som fra dem får essentielle dele af det nukendte menneskelige liv. I begge myter tager forbindelsen imellem menneske og jaguar skikkelse som slægtskabsrelationer: Drengen adopteres af en faderlig jaguar, og den voksne jæger får en jaguarkvinde som kone og dermed en jaguar som svigerfar. En vigtig forskel imellem dem er deres 'meddelelser', altså deres ætiologier: Mens ilden kommer til at definere det daglige køkken, udgør honningfesten en festlig undtagelse og afbrydelse af daglige rutiner, svarende til forskellen imellem stegt kød og honning, som repræsenterer hhv. daglig rutine og en dramatisk undtagelse. Honningen afviger fra det daglige køkken ved at kunne spises som den er, uden tilberedning over ild, eller den kan gæres til en alkoholisk, festlig drik.

4 Wahley \& Galvão 1949, 144: "beautiful songs"; også kropsdekorationer.

5 Lévi-Strauss 1964, 74-81 og mange steder i Mythologiques; en kort introduktion i Lundager Jensen 2015. 
Det er altså oplagt at forstå disse to myter som gensidige transformationer, hvilket er typisk for myter og ofte nemt at påvise (hvis man har nok versioner til rådighed; jf. Lévi-Strauss 1966, 29f.). Men det vil være lige så nærliggende at minde om en tredje myte, der udgør en transformation i en anden retning. I Andre verdener har jeg som eksempel på animistisk ontologi parafraseret en canadisk myte om en jæger, der bliver gift med en hjortekvinde og som kan overbringe sine menneskelige fæller reglerne for ansvarlig og respektfuld jagt. Hvis disse regler overholdes, vil hjortene fortsat lade sig nedlægge og dermed give menneskene kød at spise. ${ }^{6}$ Her er jægeren ganske vist ingen 'fugleredeplyndrer' (selv om også denne figur er velkendt i myter fra det nordvestlige Nordamerika: Lévi-Strauss 1971). Til gengæld besøger også han dyrenes sted der er under jorden, og oplever dem uden deres normale kostumer; han skifter selv imellem menneske- og hjorteskikkelse, gifter sig med en dyre-kvinde og kan informere sine medmennesker om vigtige, rituelle regler. Også denne mytes meddelelse har med det alimentære felt at gøre - her ikke med tilberedningen over ild eller med en lettilgængelig føde som honningen, men med materialet for det basale køkken: kødet. ${ }^{7}$

De vigtigste ligheder og kontraster imellem disse tre myter kan sammenfattes som en trekant:

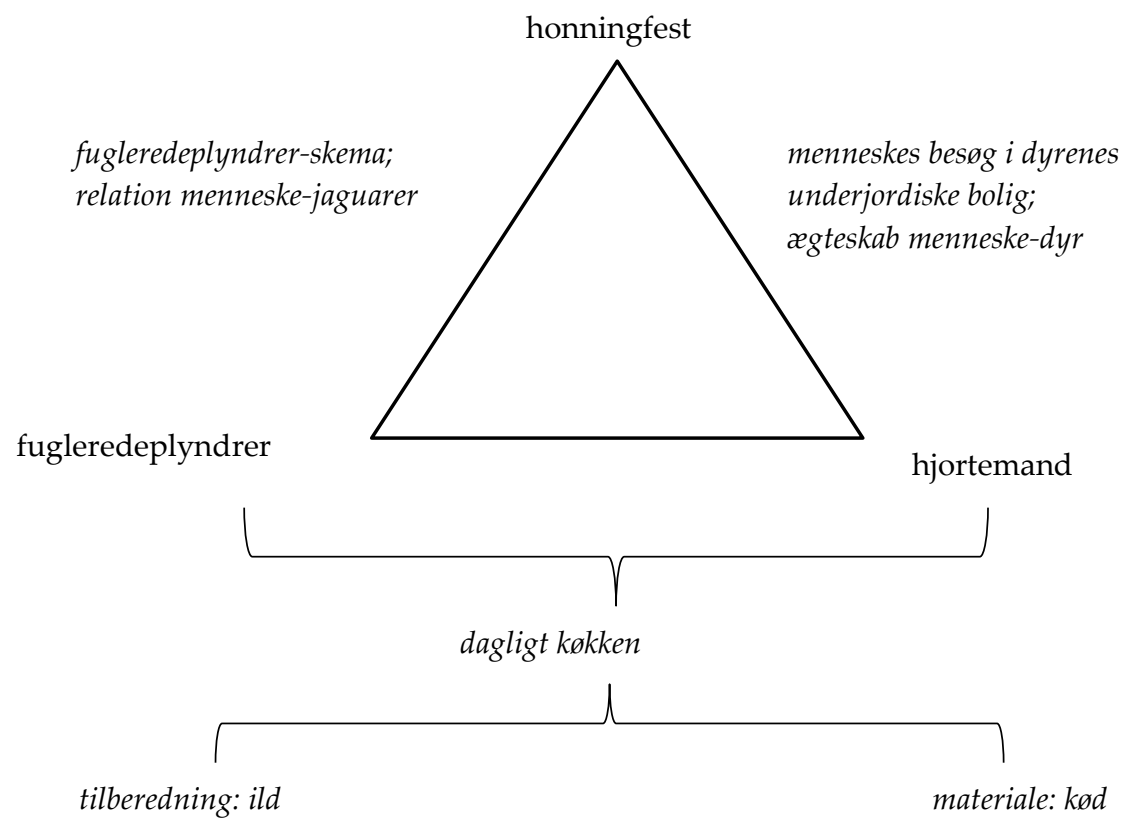

6 Fibiger \& Lundager Jensen, eds., 2020, afsnit 2.2.1. Fortælletypen er 'ekstremt almindelig', ifølge Descola $(2013,14)$.

7 Hjortemandsmyten er ikke (mig bekendt) analyseret af Lévi-Strauss selv under dette aspekt; han nævner myten kort, men opholder sig mere ved en variant, hvor hjortenes rolle spilles af bjerggeder (Lévi-Strauss 1991, 96-102); begge versioner er fyldigt gengivet af James Teit: bjerggedeversionen i Teit 1912, 258-264; hjorteversionen i Teit et al., 1917, 40-43. 


\section{Amerindisk mytologi: adskillelse imellem natur og kultur?}

Ifølge Lévi-Strauss vil disse myter i sidste instans alle have den samme meddelelse: at forklare adskillelsen imellem natur (repræsenteret ved dyrene) og kultur (menneskenes verden). De skal finde sted i en tid hvor der ikke var forskel imellem mennesker og dyr, hvor grænserne altså var flydende og identiteterne ikke endeligt fastlagt, og de slutter i en tilstand hvor der er klare grænser.

Fugleredeplyndrermyten kan umiddelbart forekomme at være et slående eksempel på en sådan belæring, for her overlader jaguaren køkkenilden til menneskene og accepterer selv at spise råt kød. Men de to andre af de tre myter, jeg her har udvalgt, lægger ikke op til en sådan konklusion. Jaguarerne lader menneskene få andel i deres viden om honningfesten; men intet antyder at de selv skulle ophøre med at fejre den. Tilsvarende forklarer hjortene menneskene hvordan de bør jages (nemlig så de kan komme tilbage til livet, få et nyt hjortekostume og dermed igen kunne levere kød til menneskene). Men dermed forklarer de kun hvordan de selv lever. Hver dag tager de kostume på, jager hinanden og bringer kød med hjem; og de der er blevet nedlagt, vender tilbage som de mennesker de også er, og kan næste dag atter re-inkarnere sig (i ordets bogstavelige betydning) og blive til føde for mennesker - eller for de andre hjorte og sig selv. Menneskenes liv differentieres og beriges; dyrene mister intet af den grund, men forbliver som de særlige mennesker de er. Så hvis der her er noget der ligner en kontrast imellem 'natur' og 'kultur', er det nærmest hvordan menneskene bliver lige så 'kulturlige' som dyrene allerede er.

Lige præcis på det afgørende punkt for animismen: forholdet imellem dyr og mennesker, var Lévi-Strauss konsekvent uklar. Ganske mange steder lader han forstå at myterne udspiller sig på en tid, 'hvor der ikke var forskel imellem dyr og mennesker' eller endog at 'dyrene var menneskenes forfædre' ${ }^{8}$ Men dette går skævt af pointen i animismen som jo netop ikke er at mennesker bliver mennesker, og dyr bliver dyr, men at alle oprindeligt var mennesker, og at dyr og planter bliver til en særlig slags mennesker med særlige kroppe og derfor med særlige egenskaber.

Man forstår hvorfor Philippe Descola, den ellers respektfulde elev, i sit bidrag "Les deux natures de Lévi-Strauss" til hyldestbindet Lévi-Strauss (L'Herne 2004), har kunnet gøre det klart at Lévi-Strauss' brug af natur-kultur-dikotomien i sine mytestudier er misvisende: 'Hvis der et felt hvor distinktionen natur/kultur ikke er på sin plads, er det netop de amerindiske myter'.${ }^{9}$ Descola giver i denne sammenhæng forskellige forklaringer på hvorfor Lévi-Strauss støttede sig til dikotomien: mestendels en metaforisk

8 Lévi-Strauss 1966, 59; 1972, 526; Lévi-Strauss \& Eribon 1988, 190f. Myter (som jo kendes i vestlige gengivelser) kan selv refereres for udsagn i den retning: 'Tidligere lignede dyr mennesker' (ibid., 72); men man kan også finde ligefremme udsagn: 'I de tidligste tider var dyr mennesker' (ibid, 92).

9 "[I]f there is an area where the distinction between nature and culture does not operate, it is that of Amerindian myth" (Descola 2009, 113). 
brug; mindre etnografisk information end hvad der nu er tilgængeligt; dens metodiske eller fremstillingsmæssige uundgåelighed, i sidste instans. Descola vil dog ikke anerkende at der skulle være tale om en ureflekteret accept af den idehistoriske tradition fra Descartes der jo formulerede en indflydelsesrig udgave af sondringen imellem natur og kultur i form af dualismen imellem 'det udstrakte' og 'det tænkende' (res extensa og res cogitans). Jeg vil her foreslå at en sådan forklaring måske alligevel også har noget på sig.

\section{Adskillelse imellem himmel og jord?}

Adskillelsen imellem natur og kultur fandt Lévi-Strauss i en særlig dramatisk udgave i myter i det nordvestlige Nordamerika - beskrevet i den fascinerende afslutning i det fjerde og sidste bind, L'Homme nu, af Mythologiques. Dette, det største i serien, var helt viet til nordamerikanske versioner og transformationer af fugleredeplyndrermyten. I versioner fra det indre Oregon og nordlige Californien (stammerne Klamath og Modoc) har fortællingen ganske vist den samme lokale og beskedne form som de sydamerikanske udgaver. Men i versioner fra British Columbia (bl.a. hos de samme 'Thompson River Indians' eller rettere Nlaka'pamux, som hjortemandsmyten ovenfor kommer fra) begynder myten at antage kosmologiske dimensioner. Her nøjes helten ikke med at sidde isoleret imellem himmel og jord; han løftes helt op i himlen hvorfra han først kommer ned efter en række møder med sælsomme væsener. Og denne 'stærke' version får en ultra-stærk udgave i myter fra Stillehavskysten (Washington og Oregon). Her fortælles om en veritabel, kosmisk krig. Væsener fra jorden forsøger at storme himlen, men drives tilbage af himmelvæsener (de der ikke når tilbage, bliver til stjerner; nogle falder hårdt ned på jorden og får deres knogler knust; derfor er der fisk med mange små ben, og derfor har sneglen ingen knogler). ${ }^{10}$ Ifølge Lévi-Strauss er moralen her at den forbindelse imellem himmel og jord, der engang, i myternes tid, var mulig imellem himmel og jord, nu for evigt er lukket:

(Uanset den enkelte mytes forløb) munder de [alle myterne] ud i at kommunikationen imellem de to verdener herefter vil blive umulig. Men i form af stjerner på himlen og køkkenilden på jorden består et dobbelt vidnesbyrd om at det øvre og det nedre engang var forbundet. ${ }^{11}$

Den vertikale modsætning imellem himmel og jord er en spatial udgave af den horisontale modsætning imellem dyr og menneske, natur og kultur. Ildens herre i Lévi-

10 De nordvestlige myter om krigen imellem himmel og jord, som Lévi-Strauss inddrager, havde allerede Frazer samlet $i$ et appendiks til sin udgave af det græske mytekompendium Apollodoros' 'Bibliotek' (Frazer 1921, 318-326).

11 Lévi-Strauss 1971, 529-531: “[...] il en résulte que la communication deviendra désormais impossible entre les deux mondes. Mais, sous la forme des étoiles au ciel et du feu de cuisine sur terre, un double témoignage subsiste que le haut et le bas furent jadis réunis“. Jf. fx LéviStrauss \& Eribon 1991, 136f.: De amerindiske myter er "variations on a great theme (...): the passage from nature to culture, which must be payed for with the definitive breakdown of communication between the heavenly and earthly realms. And the result for humanity is the problems treated by this mythology." 
Strauss' sydamerikanske udgangspunkt, den generøse jaguar, er altså en jordisk horisontal udgave af den himmelske sol. Og moralen er den samme: Engang var der kommunikation imellem dyr og mennesker, himmel og jord; men det var dengang, og nu er forbindelserne afbrudt.

I denne afslutning og opsummering på Mythologiques er det den vertikale akse der er den vigtigste. Lévi-Strauss viger her ikke tilbage fra at give sit bud på religionens oprindelse, eller i det mindste på den første religiøse forestilling: bemestringen af ilden. Med magt over ilden har menneskene fået en himmelsk størrelse nede hos sig, og som gør det menneskelige liv muligt. Og han anfører at indoeuropæiske samfund har haft et fælles begreb om 'Gud', hvis etymologiske form, *deiwos, har betydet 'lysende' og 'himmelsk'. ${ }^{12}$

Mit spørgsmål er om de amerindiske myter faktisk lægger op til denne dramatiske slutning? Der er et forhold ved disse syd- som nordamerikanske samfund der givetvis er underspillet i Mythologiques: at de er shamanistiske. ${ }^{13}$ Når helten i myten om honningfesten kan besøge jaguarerne, er det fordi han er en shaman der kan skifte imellem menneske- og myrekrop - en detalje som Lévi-Strauss kun nævner i forbifarten. ${ }^{14}$ Men det må formentlig betyde at når helten ikke kan vende tilbage til jaguarerne og hans jaguarhustru, er det ikke fordi al forbindelse fra nu af er utænkelig, men fordi han ikke kan finde vejen; blodsporet er for længst forsvundet. Shamaner kan meget; men det betyder ikke at de kan alting.

Hvis en shaman kan besøge jaguarerne, kan andre shamaner besøge andre steder med andre væsener, uden for menneskenes kreds. Og at de kan forvandle sig til andre væsener, betyder blot at de har samme egenskaber som dyrene har. Men så er der ikke sket nogen endegyldig afbrydelse imellem menneskenes og andre væseners domæner: dyrenes eller himmelboernes.

\section{Animisme eller analogisme og proto-naturalisme?}

Lévi-Strauss' reference til indoeuropæere kan give mistanke om at forskellen imellem tribal og arkaisk religion ikke har stået ham klar, en forskel der i denne sammenhæng også vil være en forskel imellem animisme og analogisme. For der er nogle gennemgående træk ved netop arkaiske religioner der kan genfindes i Lévi-Strauss' kosmologiske scenarie: at forholdet imellem mennesker og magtfulde ikke-mennesker tænkes primært vertikalt, at det høje hierarkisk dominerer det lavere, og at der består et inkommensurabelt forhold imellem himmelboere og jordboere. Man kan blot tænke på

12 Ibid, 556, med henvisning til lingvisten Émile Benveniste.

13 Hvad dette spørgsmål angår er Métraux 1949 vel stadig grunlæggende (s. 588: “Outside the Andean area the religious lift of the Indians centered on the shaman, for he was the intermediary between both the individual and the community and the supernatural world and led most of the ceremonies by which help and guidance was obtained by the spirits"); jf. fx Furst 2005; Lambert 2007, 75-78.

14 Wagley \& Galvão (s. 144) siger tydeligere: “Aruwe [jægerens navn] was a shaman so he lightned his cigar and began to 'call the supernatural'". 
Genesis' fortælling om Jakob i Betel (Gen 28), hvor helten nok ser stigen imellem himmel og jord, men ikke kunne drømme om selv at ville kravle op ad den. Jakob accepterer at være og forblive jordboer (og dvs. at være lukket ude af Edens Have, himlens horisontale transformation). Lévi-Strauss' afsluttende morale, den spærrede forbindelse fra jord til himmel, passer bedre til en arkaisk religion som den der dominerer i Det Gamle Testamente. Den passer formentlig ikke ret godt med en animisme der har plads til kommunikation med dyr og planter og til menneskelige shamaners kropsskifte og besøg i andre verdener. Min mistanke er altså at Lévi-Strauss i sin afsluttende morale gør tribal religion til arkaisk religion og animisme til analogisme.

Måske ligger der mere endnu i disse forvekslinger. At insistere på at forbindelsen imellem himmel og jord og imellem mennesker og andre væsener nu er afbrudt, er ikke kun en morale som flugter med arkaisk religion og dens afstand imellem store guder og små mennesker. Den flugter også med naturalistisk ontologi. Den idehistoriske etablering af 'naturen' som et selvregulerende, materielt domæne skete som bekendt i høj grad i forskellige former for 'religionskritik' (også selv om denne igen blev sat i gang af interne forskydninger i den senmiddelalderlige teologi). Det moderne menneske skal være det der kan leve inden for 'den immanente ramme', ${ }^{15}$ uden Gud eller en gud. Fra og med arkaisk religion er vertikalitet, spændet imellem himmel og jord, i praksis nærmest ensbetydende med religion: de store guder (eller de fleste af dem) er i himlen, mennesker er på jorden: 'Fader vor, du som er i himlen'. Modernitet indebærer her en immanent 'flad', anti-vertikal, virkelighed. ${ }^{16}$ Så hvis man med LéviStrauss kan udvinde den morale af den samlede amerindiske mytologi at menneskene nu må leve alene på jorden uden forbindelse til himlen, vil naturalismen allerede her være foregrebet. Den amerindiske mytologi vil så nok være en mytologi; men i praksis vil den så lære den samme illusionsløse nøgternhed som naturalismen, i kontrast til de store religioners fantasmer om forløsning fra jordiskheden i kraft af en intakt forbindelse imellem verdener, imellem himmel og jord. Hvis denne rekonstruktion af Lévi-Strauss' ræsonnement (der sagtens kan have været ubevidst) kan have noget på sig, skyldes hans miskendelse af animismen altså at den er iscenesat som en ideologisk hyldest til naturalismen - og, en konklusion der ikke er til at undvige, en kritik af de postaksiale religioner, og givetvis primært, som den mest relevante af dem, traditionel kristendom.

Denne underforståede og konstruerede alliance imellem tribal animisme, arkaisk analogisme og naturalisme vakler. Arkaisk religion antager ganske vist at menneskene hører til på jorden (og i underverdenen). Men den ville ikke være en religion hvis der ikke var kommunikation imellem mennesker og en anden verden (eller mindst én anden verden). ${ }^{17}$ En ontisk, altså kropslig, kommunikation for menneskekroppe er ganske vist ikke mulig, hhv. prekær, for mennesker overlever dårligt et direkte møde med en himmelboer. Men der er mange andre former for kommunikation der i høj grad er

15 Taylor 2007: 'the immanent frame'.

16 John Lennons sang 'Imagine there is no heaven, it is easy if you try' kom mellem 100 og 200 år for sent; i mere end hundrede år har ingen behøvet at prøve.

17 Således Jens Peter Schjødt 2004, $19 \mathrm{f}$. 
mulige: bønner, hymner, ofringer og røgelsesrøg fra jord- til himmelboere, og drømmesyn, orakler og guddommelige væseners punktuelle tilsynekomst fra himmel- til jordboere - for ikke at nævne himmelboernes stadige overvågning og sanktionering (positivt og negativt) af jordboernes handlinger.

Der er ingen endegyldig lukning af kommunikationen imellem himmel og jord i arkaisk religion. Hverken den eller animismen kan gøres til proto-naturalisme. Moderniteten er henvist til at være alene med den illusionsløshed som Lévi-Strauss selv insisterede på. Han understregede at myterne ikke kan lære nutidsmennesker noget om virkeligheden (det er videnskabens opgave). Formuleret spydigt: 'de vil ikke komme afkræftede ideologier til undsætning'. ${ }^{18}$ Men hvorfor skulle den amerindiske mytologi så konstrueres sådan at den kom naturalismen til undsætning?

Himlen har ganske rigtigt lukket sig, selv om det ikke var i det før-koloniale Amerika det skete, men i Europa, fra og med senmiddelalderen. En fortaler for naturalismen kan sige at verden ikke af den grund er blevet mindre mirakuløs og ufattelig, snarere tværtimod. Nu er det blot ikke shamaner der kan bringe informationer om verdener uden for den daglige, men matematikere, fysikere, biologer og astronomer. Disse verdener og deres menneskelige formidlere kan oplyse om uventede former og strukturer og endog om 'den menneskelige ånd', som Lévi-Strauss så som den ultimative aktør for myteuniversets stadige transformationer. Men, som Lévi-Strauss selv fremhævede (Lévi-Strauss 1991,10-13), kan deres oplysninger måske nok forstås (af et mindretal); men man kan ikke forestille sig dem og dermed heller ikke formulere dem som myter eller legender. Man kan tilføje at de heller ikke kan fortælle os hvilke fester vi skal holde og hvordan.

\section{Litteratur}

Descola, Philippe

2013 "The Two Natures of Lévi-Strauss", in: Boris Wiseman, ed., The Cambridge

Companion to Lévi-Strauss, Cambridge University Press, 103-117.

https://doi.org/10.1017/CCOL9780521846301.006

Fibiger, Marianne Qvortrup \& Hans J. Lundager Jensen, eds.

2020 Andre verdener. Indføring i religionshistorie og religionsfænomenologi, Univers.

Frazer, James George

1921 The library / Apollodorus, bd. 2, Loebs Classical Library.

Furst, Peter T.

2005 "Shamanism: South American Shamanism", in: Lindsay Jones, ed., Encyclopedia of Religion, 2. ed., Macmillan.

Lambert, Yves

2007 La naissance des religions de la préhistoire aux religions universalistes, Armand Colin.

Lévi-Strauss, Claude

18 Lévi-Strauss 1972, 571: “ils ne viendront pas à la rescousse d'idéologiques exténuées”. 
1991 Histoire de Lynx, Plon.

1985 La Potière jalousie, Plon.

1979 La Voie des masques, Plon.

1971 L'homme nu, Plon.

1968 L'origine des manières de table, Plon, 1968.

1966 Du miel aux cendres, Plon.

1964 Le cru et le cuit, Plon.

Lévi-Strauss, Claude, \& Didier Eribon

1988 De près et de loin, Odile Jacob.

Lundager Jensen, Hans J.

2015 "Strukturalisme", in: Armin W. Geertz \& Tim Jensen, eds., Religionsforskningens før og nu. II. Nyere tid, Gyldendal, 373-406.

Métraux, Alfred

1949 "Religion and Shamanism", in: Handbook of South American Indians, Vol. 5: The Comparative Ethnology of South American Indians, The Smithsonian Institution, 559-595

Taylor, Charles

2007 A Secular Age, The Belknap Press of Harvard University Press.

Teit, James et al.

1917 Folk Tales of Salishan and Sahaptin Tribes, Memoirs of the American Folk-Lore Society 9.

1912 Mythology of the Thompson Indians, Memoirs of the American Museum of Natural History 12.

Wagley, Charles, \& Eduardo Galvão

1949 The Tenetehara Indians of Brazil, Columbia University Contributions to Anthropology 35.

Hans J. Lundager Jensen, professor, dr. theol. Afdeling for Religionsvidenskab, Aarhus Universitet 